\title{
Ethnic Politics and Democratic Consolidation in Nigeria
}

\author{
Akindiyo Oladiran \\ Department of Public Administration, Faculty of Business Studies, \\ Rufus Giwa Polytechnic, Owo, Ondo State \\ E-mail: akindiyooladiran@yahoo.com
}

DOI: 10.6007/IJARBSS/v3-i12/486 URL: http://dx.doi.org/10.6007/IJARBSS/v3-i12/486

\begin{abstract}
Ethnic diversity is not peculiarly Nigerian as other climes have plural composition. Nigeria's party history is fraught with ethnicity. This work appraises the rabid competition amongst multiethnic groups for power and wealth. This has culminated in mutual distrust and suspicion as well as heightened tensions with its attendant implications for democratic consolidation. The corollary of this is the recurring and perennial hydra-headed challenge it poses for Nationbuilding. Democratic tradition which is a sine qua non for development, cannot flourish in an ethnically conflict-ridden polity. This paper analyses the need for democratic sustenance because of its nexus with development. This is particularly imperative as the nation marches towards another democratic drive with palpable fear that ethnicity can scuttle it if not properly managed. It posits that democratic consolidation is not unattainable. The work relies on secondary source of data and concluded by making some useful recommendations.
\end{abstract}

Key Words: Ethnic Group, Ethnicism, Democratic Consolidation, Politics And Nation - Building.

Democracy does not provide a people with the most skillful of governments but it does that which the skilful government often cannot do. It spreads throughout the body social, a restless activity, super abundant force, and energy never found elsewhere, which, however little favoured by circumstances can do wonders. Those are its true advantages.

(Alexis de Tocqueville)

\section{Introduction}

It is incontrovertible that Nigeria is multi-ethnic and the inter-play of this ethnic factor pose a certrifugal and daunting challenge to the corporate existence of Nigeria as a nation. Expectedly, politics by its nature and character is to give birth to a democratic structure capable of engendering development.

However, in Nigeria, owing to incessant military coups coupled with the ethnicisation of politics even before independence, it has assumed a dangerous dimension by becoming a barometer for measuring contribution to nation building. It is now an instrument for allocating and distributing power and national resources. As Nigeria experiences a new democratic drive with the rising spate of insecurity, pundits believe this has ethnic as well as political undertone but dressed in Boko Haram garment. It is therefore trite to handle it with utmost caution and sincerity. Thousands of lives not to mention properties have gone as a result of this insurgence. 
Hitherto, no serious effort have been made at nipping the menace in the bud. It is against this background that this paper discusses implications of ethnic politics on democratic consolidation in Nigeria.

The paper will equally examine the elusiveness of democratic consolidation with a view to making some recommendations on democratic sustenance in Nigeria.

\section{Conceptual and Theoretical Framework}

In view of the fact that concepts may have both cultural and ideological conceptualizations and similarity owing to the fact that like power, justice, peace and equality, such concepts are what (Gallie, 1962) calls an "essentially contested" (Weldon, 1981) also subscribes to this position that they can generate unsolvable debates about their meanings and application. It is therefore imperative to give meaning to concepts such as ethnic group and ethnicity to enhance a better understanding of the subject matter being examined.

Ethnic group is an informal interest group whose members are distinct from the members of other ethnic groups within the larger society because they share kinship, religious and linguistics ties (Cohen, 1974). (Nnoli, 1978) defines ethnicity as a social phenomenon that is associated with interactions among members of different ethnic groups. He further explained that ethnic groups are social formations distinguished by the communal character of their boundaries. Such groups may be distinct in terms of language, culture, or both. According to Nnoli, language has clearly been the most crucial dividing factor in Africa.

Ethnicity should be seen as arising in any situation where a group of people, no matter how small, with different cultural and linguistic attributes from those of its neighbours; uses this as the basis of solidarity and interaction with others. In so doing, the group sees itself not only as distinct, but as a "group in itself and for itself". (Edlyne, 2000). Put differently, socio-cultural consciousness of oneness develops and forms the basis of interaction with and participation in other socio-cultural processes, especially in power and resource allocation, within a larger social group or state.

From the conceptualization of these two related concepts, it can be seen that ethnicity is a phenomenon, which involves interaction among various ethnic groups and which by itself does not pose any serious threat to either development or democracy. On the contrary, it is the phenomenon of negative ethnicism, which is rejective attitudes towards those regarded as outsiders that threatens nation-building. (Salawu \& Hassan, 2011). They further posit that it was the term ethnicity that was found among Nigerians before the coming of the Europeans, while the second term (ethnicism) is a product of competition for both economic and political resources. The problematic nature of ethnicism as conceptualized above can be explained in the context of some theoretical positions.

Firstly, one can analyse the negative aspect of ethnicism by linking it to the theoretical framework of the elite pluralist theory. Generally, classical pluralists posit that society is made up of several groups with interests which may be at variance. Thus, there could be sectional interests such as class, gender, religious and ethnic interests. Where an individual pits his tent on any political matter is, therefore, a factor of all his many interests which may include class, religion and ethnicity. Some of the fundamentals of the elite pluralist theory are stated below:

* members of society do not have exactly the same amount of power; 
the elite and the leaders of groups are the main participants in decision making (Haralambos, Holborn \& Heald, 2000).

Another explanation for why ethnicism has become a problem to contend with is possible in the context of conflict theory. Social conflict can be defined as a struggle over values or claims to status, power and scarce resource in which the aims of the conflicting parties are not only to gain desirable values but also to neutralize, injure and/or eliminate their rivals. (Salawu and Hassan, opcit, 2011).

In Nigeria, it is this ethnicity that is being exploited by ethnic chauvinists when politics is involved. It is however sad that owing to the fact that democracy has not been deepened, development is a mirage. The above therefore may not be unconnected with ethnic colouration being given to virtually all matters thereby necessitating the ethnic question in Nigeria. This human attitude manifests in form of prejudice and tribalism (ethnic communalism and conflict). The aspect of prejudice that is relevant to our discussion here is the one that has to do with group solidarity. (Peil, 1977) claims that group solidarity provides security in situation of potential conflict and informal support when official agencies cannot or will not help. Prejudice can be turned to discrimination. If this happens, there will be strong pressure to exclude outsiders in the sharing of scarce resources such as political power.

At this juncture, it is important to give a brief insight into the concept of democratic consolidation. Originally, the term "democratic consolidation" was meant to describe the challenge of making new democracies secure of extending their life expectancy beyond the short-term of making them immune against the threat of authoritarian repression of building dams against eventual "reverse waves" (Ojo, 2006). However, the list of democratic consolidation (as well as the corresponding list of "conditions of democratic consolidation"), has expanded beyond all recognition (Beetham, 1994). It has come to include such divergent items as popular legitimating, the diffusion of democratic value, the routinisation of anti-system actors, civilian supremacy over the military, the elimination of authoritarian enclaves, party building, the organization of functional interest, the stabilization of electoral rules, the routinisation of politics, the decentralization of state power, the introduction of mechanisms of direct democracy, judicial reform, the alleviation of poverty and economic stabilization in the words of (Andreas, 1998). Summarily put, (Whitehead, 1989) believes that democracy can best be said to be sustained or consolidated only when we have good to believe that it is capable of withstanding pressure or shocks without abandoning the electoral process or the political freedom on which it depends, including those of the dissent and the opposition. Definitely, this will also require a depth of institutionalization reaching beyond the electoral process itself.

\section{Interplay Of Ethnicity In The Body Politics Of Nigeria: An Overview}

In the pre-colonial era and since the independence of Nigeria, ethnicity played and is still playing manifest and latent roles in the body politics of Nigeria. As (Otite, 1990) observed and quite rightly too, the ethnic virus has been one of the most important causes of social crisis and political instability in Nigeria; and ethnicity has been perceived in general as a major obstacle to the overall politic-economic development of the country.

In pre-independence era, party politics in Nigeria was based on ethnic factor. One can say without mincing words that it was during this period in question that the seed of ethnic politics was sown, germinated in the First Republic and the products started spreading during 
the Third and Fourth republics. For example, the Action Group (AG) as a party led by Chief Obafemi Awolowo developed from a Yoruba Cultural Association, Egbe Omo Oduduwa; the National Council of Nigeria and the Cameroon (NCNC), later renamed National Council of Nigerian Citizen led by Dr. Nnamdi Azikwe was closely allied with the Igbo Union while the Northern Peoples Congress (NPC) developed from Jamiyyah Arewa led by Sir Ahmadu Bello. Thus the leadership of the aforementioned parties was along ethnic cleavages. Even to a large extent, the colonial administrative arrangement in Nigeria during the Colonial period encouraged ethnic politics. The division of Nigeria into three regions in 1946 by Richard Constitution for administrative convenience was directly associated with the three major ethnic groups - Yoruba, Hausa and Igbo. It is not surprising therefore that the first political parties were formed along ethnic lines. During the first republic, politics was organized in the same way as during the pre-colonial era. It was still the AG, NCNC, NPC and other minor parties like the Northern Elements Progressive Union (NEPU) by Aminu Kano; and United Middle Belt Congress (UMBC) led by Joseph Tarka. There was no radical departure from those of the pre-colonial era as the parties had ethnic colouration in terms of leadership and regional affiliations.

However, it was in the Second Republic that regionalism was played down a bit. And it was because the 1979 constitution stipulated that for a political party to be registered, it must be national in outlook. The new political parties that were registered had their leadership replicated along ethnic lines as in the first republic. Thus, Obafemi Awolowo retained the leadership of AG which metamorphosed into Unity Party of Nigeria (UPN), Nnamdi Azikiwe controlled the Igbo speaking areas under Nigeria's People Party (NPP), which is an offshoot of the old NCNC. National Party of Nigeria (NPN) dominated the Hausa-Fulani areas; Peoples Redemption Party (PRP) in Hausa speaking while Great Nigeria Peoples Party (GNPP) led by Ibrahim Waziri controlled the Kanuri speaking area. Therefore, ethnic colouration and affiliation played out in political parties formation and operation during the $2^{\text {nd }}$ Republic. Voting patterns equally followed ethnic lines in the elections (James, 2011).

It should be pointed out that political parties formation had a different dimension in the Third Republic which was midwived by President Ibrahim Babangida's government. These were the Social Democratic Party (SDP) and the National Republican Convention (NRC). Even though these parties were established by government, ethno-religious cleavages were visible in the membership and composition of the two parties. While the SDP favoured the southerners, NRC was a party for the Hausa-Fulani North as could be observed from their operation.

In the current political dispensation of the Fourth Republic, ethnic colouration has reared its ugly head. The All Nigeria's Peoples Party (ANPP), Alliance for Democracy can still be traced to Hausa-Fulani and Yoruba ethnic groups. The ruling Peoples Democratic Party (PDP) is being perceived as to have deviated a bit from the usual ethno-religious dominated party politics of the past with their membership and formation cutting across the clime of Nigeria. However, in the 2011 general elections, inspite of change of names of some political parties and registration of new ones, ethnic and regional politics played itself out. The death of Alhaji Umar Musa Yar'adua changed the power configuration to the south and the north is insisting on producing the presidency come 2015. The merging of parties as well as re-alignment of forces in this regard cannot be divorced from either the contest for power or/and resources. The political instability occasioned is borne out of who gets what, when and how. The link between 
ethnic conflict and democracy is especially crucial in view of the popular assumption that democracy engenders development.

Much historical evidence shows, however, that development has not been possible where there are marked divisions or intense conflicts between groups in a given society. Therefore, ethnic conflicts negate the development function of democracy and may ultimately attack the roots of democracy in a society. (Edlyne, opcit).

\section{Why Democratic Consolidation Is Elusive In Nigeria?}

Undoubtedly, there is a nexus between good governance which is synonymous with development and democratic consolidation. Democratic consolidation should be the foundation upon which good governance rests. Owing to so many factors to be examined here, it is now a wishful thinking in Nigeria.

Ethno-religious factor remains one of the forces that contributed greatly to the sociopolitical instability in the country. According to (Mazuiri, 2001), amongst the things that trigger the sharia advocacy in some northern states of Nigeria, was the resentment of being at the periphery of Nigerian politics and power configuration.

Poverty, hunger and unemployment is another major challenge to democratic consolidation as the essence of leadership in any social context is improvement of welfare of members of the society. Over the years, there has been deliberate neglect or lip service attention to these issues; consequently, it has impoverished the citizenry and exposed them to easy manipulation for violent culture.

Of note again is corruption. The institutionalization of corrupt culture in all sphere of public activities is perhaps the major challenge to survival of democracy in Nigeria. (Akanbi, 2013) captures the situation thus "there is a general desecration of societal and normative value, low level performance in socio-economic and technological developments and ultimately a petrifying decadence, the stench of which often puts off or prevent other nations with a record of transparency and probity from wanting to interact or do business with a corrupt nation. He stated further that there would be no development in a society that is taken over by corruption and corrupt leaders.

Also, Youth restiveness rears its ugly head as a hurdle to democratic consolidation in Nigeria. The saying that the Youth are leaders of tomorrow must be guaranteed practically. There is a failure to develop a policy with sincere commitments to regenerate confidence of youths as therapy to restiveness. Lending credence to this, (Kennedy, 1960) has this to say, "this world demands the qualities of youth; not a time of life but a state of mind, a temper of will, a quality of imagination, a predominance of courage over timidity, of the appetite for adventure over the life of ease".

Again, the exaggeration of indigene-settlers dichotomy in Nigeria has inflamed conflict dimension in the polity with severe impact on national cohesion. This above phenomenon eve though unconstitutional is well engraved in the sub-consciousness of the leadership of most states of the federation. This has been largely responsible for spate of crisis in Nigeria, particularly in the North.

Similarly, free, fair and credible election is a must to sustain democracy. Electoral fraud poses a major threat to democracy and by implication weakens its capacity as an instrument for the mobilization of national, human and material resources for the development of the people 
and the state. The above is an albatross in the democratic drive in Nigeria. There is again the absence of true federalism.

Aside the structural imbalance of Nigerian federation, absence of true federation the revenue allocation as well as resource control debacle is contentious. Where equity and fair play are missing, it may work against the evolvement of sustainable democracy.

Regarding the security question, beyond the effects of security concerns on the economic fortunes of the security challenges facing the country, it also have implications for the country's political system. Social cohesion among various groups and interests is important in the process of national political development. The activities of the Niger-Delta militants, militia groups like Odua Peoples Congress (OPC), Movement for the Actualisation of Sovereign State of Biafra (MASSOB), EGBESU and constant sectarian turmoil exemplified by the activities of Boko Haram put together is a major obstacle to democratic consolidation. Hobbes puts it aptly (Leviathan, 1651), that "the state of nature was one in which there were no enforceable criteria of right and wrong. Each person took for himself all that he could; human life was "solitary, poor, nasty, brutish and short". "A war of all against all".

\section{Conclusion and Recommendations}

It is unarguable that unfolding developments within the nation since the inception of this democratic experiment have generated debates and anxiety across all walks of life about the future of Nigerian federation. Attesting to this are the challenges of democratic consolidation chronicled above as a result of failure of Nigerian nation to contend with them. Singling out the insurgency question - Boko Haram, it has been so much exaggerated and mystified that phobia and mutual suspicion determines every aspect of public relationship. This is not to be because economic and social activities have been in comatose in most commercial cities in the Northern states, thereby justifying the basis for the debate that the state of the union is in jeopardy particularly as another major elections draw nearer and democratic sustenance is imperative. This however makes the issue of National Question a desideratum. Commenting on it, (Ajayi, 1992) argued that the National Question is ... the perennial debate as how to order the relations between the different ethnic, linguistic and cultural groupings so that they have the same rights and privileges, access to power and equitable share of national resources. In alliance with the above position is (Ayobolu, 2013) "the country's cultural diversity is a veritable strength, a critical resource that should be tapped for our collective benefit. The way to do this is not to pretend that these significant cultural differences do not exist or try to suppress and dissolve them into a mythical Nigerian nationhood". "Rather free reign and institutional expression must be given to diverse cultures, values, beliefs, ideas, mores and norms of the component peoples of Nigeria so that the maximum realization of the potentials of each part becomes the collective strength of the whole".

Whatever may be the postulations of ethnic chauvinists, power brokers and cynics, one thing is certain. And it is that inspite its tortous journey, the democratic experiment since 1999 to date is the longest in Nigeria's political history, an indication that all hope is not lost. Taking a line of thought that bothers on democratic consolidation connotes that, to a reasonable extent some foundation has been laid for democracy to flourish. Making it enduring is the next major pre-occupation. It is in the light of this that the following recommendations are made to assuage the daunting challenges of democratic sustenance. These are: 
- $\quad$ leadership with commitment

- $\quad$ strengthening democratic institutions

- transparency and accountability

- $\quad$ addressing the national question through convocation of National Conference

- $\quad$ reduction of hunger, poverty, unemployment and Youth restiveness

- $\quad$ participatory democracy - broadening participation through political education by National Orientation Agency (NOA) and the Mass Media

- building of institutional capacity in citizens' welfare

- $\quad$ addressing security question

- diversification of the economy while focusing attention or agricultural and food security

- $\quad$ result-oriented Ministries, Departments and Agencies (MDAs) at all levels of government

- $\quad$ re-orientation through churches, mosques and schools

- $\quad$ promotion of gender balance.

Even though the recommendations made above are by no means exhaustible, one may rest one's case by saying if the above are considered and followed, a lot will be achieved. And ethnic politics reduced to its bearest minimum with democratic consolidation, two sides of the same coin with good governance. The following insightful comment made by Late American President Calvin Coolidge while preaching for restoration of confidence in national institutions in the early part of the $20^{\text {th }}$ century will serve as an epilogue:

We need a broader, firmer, deeper faith in the people. A faith that men desire to do right, that the commonwealth is founded upon a righteousness which will endure, a reconstructed faith that the final approval of the people is given not to demagogues, slavishly pandering to their selfishness, merchandising with the clamour of the hour but to statemen, ministering to their welfare, representing their deep, silent abiding convictions (Bola, 2009).

\section{References}

1. Cited in a front page of editorial comment entitled "two years of democracy" in Nigerian Tribune, Ibadan, $29^{\text {th }}$ May, 2000 pp 1 \& 10.

2. W.B. Gallie, "Essentially contested concept", in Max Black (ed), The Importance of Language, New Jersey, Prentice Hall, 1962 p.1

3. Cited in Richard Little, "Ideology and Change in Barry Buzan and R.J. Jones (eds), change and the study of International Relations, London, Frances Printers, 1981, p. 35

4. Cohen A, 1974, Urban Ethnicity, London, Taristock Publications Ltd.

5. Nnoli O., 1978, Ethnic Politics in Nigeria, Enugu, Fourth Dimension Publishing Co. Ltd. 
6. Edlyne, E., 2000, Ethnic Conflict and Democracy in Nigeria: The Marginalisation Question, in Journal of Social Development in Africa, 2000, 15,1, pp61-78.

7. Salawu, B. and Hassan, A.O., Ethnic Politics and its Implications for the Survival of Democracy in Nigeria, in Journal of Public Administration and Policy Research Vol. 3(2) pp 28-33 February 2011.

8. Haralambos, M. Holborn, M. and Heald, R. 2000, Sociology: Themes and Perspectives, London, Hapercollins Publishers Limited. P 599

9. Peil M. 1977, Consensus and Conflict in Africa Societies: An Introduction to Sociology, Addison-Wesley Longman Ltd.

10. Ojo E.O., 2006, Imperatives of Sustaining Democratic Values, in Challenges of Sustainable Democracy in Nigeria, Ojo E.O. (ed), John Archers Publishers Ltd. P 5.

11. Beetham's, "Conditions for Democratic Consolidation", Review of African Political Economy, No. 60, 1994 pp. 157-172.

12. Andreas Schedler, "What is Democratic Consolidation?" Journal of Democracy, Vol. 9, (2) April, 1998, pp. 91-107.

13. Whitehead, L., "The Consolidation of Fragile Democracies" in Robert A. Pastor (ed), Democracy in the Americas; stopping the pendulum, Holmes and Meier, 1989.

14. Otite O., 1990, Ethnic Pluralism and Ethnicity in Nigeria, Ibadan, Shaneson C.I. Ltd.

15. James, O., Ethnic Politics in Nigeria, July 20, 2011, Nigeria Exchange News, Ngex, on-line.

16. Edlyne, opcit

17. Mazuri, A., 2001, "Shariacracy and Federal Models in Era of Globalisation: Nigerian Comparative Perspective," www.gamji.com, March 2001.

18. Daily Post, Nigeria online Newspaper, April 24, 2013.

19. Robert Kennedy, "Day of Affirmation", University of Cape Town, South Africa, June 6, 1966.

20. "Social contract" Encyclopedia Britannica, Ultimate Reference suite, Chicago: Encyclopedia Britannila, 2012.

21. Ajayi, A., 1992, "The National Question in Historical Perspective" Text of the Fifth Guardian Newspaper Lectures, Guardian, $5^{\text {th }}$ November.

22. Segun, A. cited in Ethnicity, Class and Democracy, The Nation, Saturday, August $10^{\text {th }}$, 2013, p.64

23. Cited in the Lecture delivered by Asiwaju Bola Ahmed Tinubu, former Governor of Lagos State, at a National Symposium on 10 years of Democracy (1999-2009), organized by the Aminu Kano Centre for Democratic Research and Training, Mambayya House, Bayero University Kano, Kano State, on 29 May, 2009. Titled: Democratic Consolidation in Nigeria: Issues, Challenges and Prospects. 